\title{
Penerapan Asuhan Keperawatan Jiwa Pada Tn. S Dengan Masalah Isolasi Isosial: Menarik Diri
}

\section{Sururin Maudhunah¹, Arjun Prajun Siagian², Juni L Purba3, Yola Hermanisa4, Yuli Permata Sari ${ }^{5}$}

\author{
Sururinm@gmail.com
}

\section{BAB 1 \\ PENDAHULUAN}

\subsection{Latar Belakang}

Skizofrenia merupakan sekelompok reaksi psikotik yang mempengaruhi berbagai area fungsi individu, termasuk berpikir, berkomunikasi, menerima, menginterpretasikan realitas, merasakan dan menunjukkan emosi serta penyakit kronis, parah, dan melumpuhkan, gangguan otak yang ditandai dengan pikiran kacau, waham, halusinasi, dan perilaku aneh (Pardede, 2018). Skizofrenia merupakan salah satu diagnosa medis gangguan jiwa berat yang sering terjadi di Indonesia. Skizofrenia termasuk masalah kesehatan masyarakat yang menjadi perhatian karena dampak dari skizofrenia bukan hanya dirasakan oleh penderita dan keluarga tetapi juga masyarakat serta pemerintah (Kurniasari, Dwidiyanti \& Padmasari 2019).

Pasien skizofrenia sering mendapat stigma dan diskriminasi yang lebih besar dari masyarakat sekitarnya dibandingkan individu yang menderita penyakit medis lainnya. Penderita skizofrenia biasanya timbul pada usia sekitar 18-45 tahun, dan berusia 11-12 tahun menderita skizofrenia Isolasi sosial yang dialami oleh individu dan dirasakan saat didorong oleh keberadaan orang lain dan sebagai pernyataan negative atau mengancam. Batasan karakteristiknya antara lain tidak menganggap penting dukungan dari orang lain, afek tumpul, adanya bukti cacat (fisik atau mental), sakit, tindakan yang tidak berarti, tidak ada kontak mata, dipenuhi oleh pikiran sendiri, 
menunjukkan permusuhan, tindakan berulang, sedih, senang sendiri, tidak komunikatif dan menarik diri (Damanik, Pardede \& Manalu, 2020).

Isolasi sosial merupakan kondisi kesendirian yang dialami oleh individu dan dipersepsikan disebabkan orang lain dan sebagai kondisi yang negatif dan mengancam .Kondisi isolasi sosial seseorang merupakan ketidakmampuan klien dalam mengungkapkan perasaan klien yang dapat menimbulkan klien mengungkapkan perasaan klien dengan kekerasan. Klien dengan isolasi sosial tidak mampunyai kemampuan untuk bersosialisasi dan sulit untuk mengungkapkan keinginan dan tidak mampu berkomunikasi dengan baik sehingga klien tidak mampu mengungkapkan marah dengan cara yang baik (Sukaesti, 2019).

Menurut data World Health Organization (2016), terdapat sekitar 21 juta orang terkena skizofrenia, 35 juta orang terkena depresi, 47,5 juta orang terkena dimensia serta 60 juta orang terkena bipolar dan telah memperkirakan jumlah penderita skizofrenia di Amerika 14.8 orang per 100.000 penduduk, di Afrika 1.7 orang per 100.000 penduduk, dan di Asia Tenggara 5.3 orang per 100.000. Menurut data Riskedas (2018) di Indonesia sejak usia 20 tahun presentase depresi mencapai 8 persen atau sekitar 16 juta orang (Latifah \& Rahayu, 2020).

Menurut (Sinaga, 2020) di Medan pada saat studi pendahuluan didapat jumlah pasien isolasi sosial pada tahun 2018 sebanyak 224 orang $(5,6 \%)$, dan merupakan diagnosa ketiga terbesar setelah halusinasi $(79,8 \%)$ dan defisit perawatan diri (6,5\%). Dampak dari perilaku klien isolasi sosial sering tidak dijadikan prioritas karena tidak mengganggu secara nyata. Namun apabila isolasi sosial tidak ditangani, maka akibat yang ditimbulkan dapat berupa risiko perubahan sensori persepsi : halusinasi sebagai bentuk gejala negatif yang tidak tertangani dan dapat memicu terjadinya gejala positif (Kirana, 2018). 
Dalam mengatasi masalah gangguan interaksi pada pasien gangguan jiwa khususnya pasien isolasi sosial dapat dilakukan upayaupaya tindakan keperawatan bertujuan untuk melatih klien melakukan interaksi sosial sehingga klien merasa nyaman ketika berhubungan dengan orang lain. Salah satu tindakan keperawatan tersebut yang termasuk kelompok terapi psikososial adalah Terapi Aktivitas Kelompok (TAK) Sosialisasi (Sinaga, 2020).

\subsection{Rumusan Masalah}

Berdasarkan latar belakang masalah terseby maka dapat dirumuskan masalah sebagai berikut: bagaimana pemberian asuhan keperawatan jiwa pada $\mathrm{Tn} . \mathrm{S}$ dengan isolasi Sosial di yayasan pemenang jiwa sumatera.

\subsection{Tujuan}

Adapun tujuanya sebagai berikut :

\subsubsection{Tujuan Umum}

Setelah mengikuti kegiatan ini klien dapat lebih menerapkan stategi pelaksanaan Isolasi Sosial dalam mengontrol Perilaku Isolasi Sosial.

\subsubsection{Tujuan Khusus}

1. Mahasiswa mampu mengetahui defenisi, tanda dan gejala, faktor penyebab, mekanisme koping, penatalaksanaan pada pasien dengan Isolasi Sosial.

2. Mahasiswa mampu melakukan pengkajian kepada kpasien dengan Isolasi Sosial.

3. Mahasiswa mampu menegakkan diagnosa atau masalah keperawatan kepada Tn. S dengan Isolasi Sosial.

4. Mahasiswa mampu menetapkan Intervensi keperawatan secara menyeluruh kepada Tn. S dengan Isolasi Sosial.

5. Mahasiswa mampu melakukan tindakan keperawatan sesuai Intervensi keperawatan yang ditetapkan secara menyeluruh kepada Tn. S dengan Isolasi Sosial. 
6. Mahasiswa mampu mengevaluasi sebagai tolak ukur guna menerapkan asuhan keperawatan pada Tn.S dengan Isolasi Sosial.

7. Mahasiswa mampu mendokumentasikan asuhan keperawatan pada Tn.S dengan Isolasi Sosial.

\section{4 manfaat}

1. Pasien

Diharapkan tindakan yang telah di ajarkan dapat diterapkan secara mandiri untuk mengontrol emosi dan untuk mendukung kelangsungan kesehatan pasien.

2. Yayasan Pemenang Jiwa Sumatera

Diharapkan dapat menjadi acuan dalam menangani atau dalam memberikan pelayanan kepada pasien dengan gangguan jiwa dengan Isolasi Sosial. 


\section{BAB 2 \\ TINJAUAN TEORITIS}

\subsection{Konsep isolasi sosial}

\subsubsection{Definisi Isolasi sosial}

Isolasi sosial meruakan keadaan dimana sseorang individu mengalami penurunan atau bahkan sama sekali tidak mampu berinteraksi dengan orang lain disekitarnya. Pasien isolasi soasial mengalami gangguan dalam berinteraksi dan mengalami perilaku tidak ingin berkomunikasi dengan orang lain disekitarnya, lebih menyukai berdiam diri, mengurung diri, dan menghindar dari orang lain (Damanik, Pardede \& Manalu, 2020).

isolasi sosial merupakan keadaan kesepian yang dialami oleh seseorang karena orang lain dianggap menyatakan sikap negatif dan mengancam bagi dirinya. Isolasi sosial adalah keadaan dimana seorang individu mengalami penurunan fungsi pikiran dan perilaku atau bahkan sama sekali tidak mampu berinteraksi dengan orang lain disekitarnya isolasi sosial sebagai suatu pengalaman menyendiri dari seseorang dan perasaan segan terhadap orang lain sebagai sesuatu yang negatif atau keadaan yang mengancam. (Pardede, Hamid \& Putri, 2020).

Isolasi sosial merupakan kondisi kesendirian yang di alami oleh individu dan dipersepsikan disebabkan orang lain dan sebagai kondisi yang negatif dan mengancam. Kondisi isolasi sosial seseorang merupakan ketidakmampuan klien dalam mengungkapkan perasaan klien yang dapat menimbulkan klien mengungkapkan perasaan klien dengan kekerasan.Perilaku kekerasan merupakan respon destruktif individu terhadap stresor. Klien dengan isolasi sosial tidak mampunyai kemampuan untuk bersosialisasi dan sulit untuk mengungkapkan keinginan dan tidak mampu berkomunikasi dengan baik sehingga klien tidak mampu mengungkapkan marah dengan cara yang baik (Sukaesti, 2018). 


\subsubsection{Tanda dan Gejala}

Menurut Zakiah, Hamid, \& Susanti, (2018), tanda dan gejala yang dimilki isolasi social adalah sebagai berikut

1. Wajah murung

2. Sulit tidur

3. Gelisah

4. Lemah

5. Kurang bergairah, dan

6. Malas beraktifitas

7. Menarik diri

8. Menjauhi orang lain

9. Tidak atau jarang melakukan komunikasi tidak ada kontak mata,

10. Kehilangan minat,

11. Malas melakukan kegiatan sehari-sehari atau aktivitas sosial,

12. Berdiam diri di kamar,

13. Menolak hubungan dengan orang lain, dan

14. Tidak mau menjalin persahabatan.

\subsubsection{Rentang Respon}

Dalam membina hubungan social, individu berada dalam rentang respon yang adaptif sampai dengan maladaptive. Respon adaptif merupakan respon yang dapat diterima oleh norma-norma social dan kebudayaan yang secara umum berlaku. Sedangkan respon maladaptive merupakan respon yang dilakukan individu dalam menyelesaikan masalah yang kurang dapat diterima oleh norma social dan budaya setempat. Respon social yang maladaptive yang sering terjadi dalam kehidupan sehari hari adalah menarik diri, tergantung (dependen), manipulasi, curiga, gangguan komunikasi dan kesepian (Muthith, 2015). 
Respon Adatif

Respon Maladatif
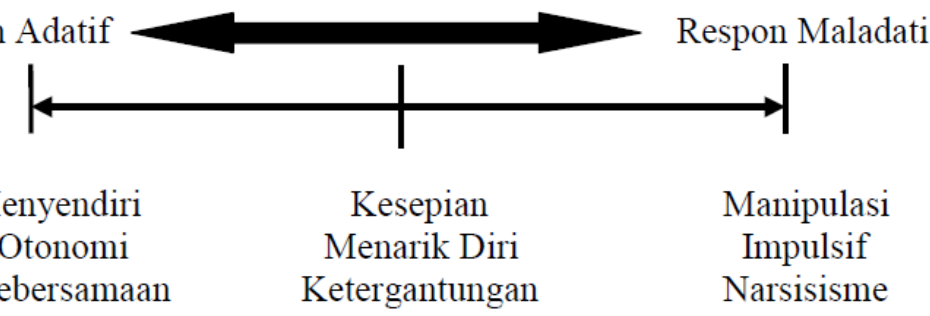

Menyendiri

Otonomi

Kesepian

Menarik Diri

Kebersamaan

Ketergantungan

Narsisisme

Saling Ketergantungan

Respon adaptif adalah respon individu dalam menyelesaikan dengancara yang dapat diterima oleh norma-norma masyarakat. Menurut Muthith (2015) respon ini meliputi:

a. Menyendiri

Menyendiri merupakan respon yang dilakukan individu untuk merenungkan apa yangtelah terjadi atau dilakukan dan suatu cara mengevaluasi diri dalammenentukan rencana-rencana.

b. Otonomi

Otonomi merupakan kemampuan individu dalam menentukan dan menyampaikan ide, pikiran, perasaan dalam hubungan sosial, individu mampu menetapkan untuk interdependen dan pengaturan diri.

c. Kebersamaan

Kebersamaan merupakan kemampuan individu untuk saling pengertian, saling memberi, dan menerima dalam hubungan interpersonal.

d. Saling ketergantungan

Saling ketergantungan merupakan suatu hubungan saling ketergantungan saling tergantung antar individu dengan orang lain dalam membina hubungan interpersonal.

Respon mal adaptif adalah respon individu dalam menyelesaikan masalah dengan cara-cara yang bertentangan dengan norma-norma agama dan masyarakat. Menurut Muthith (2015) respon mal adaptif tersebut adalah: 
a. Manipulasi

Manipulasi merupakan gangguan sosial dimana individu memperlakukan orang lain sebagai objek, hubungan terpusat pada masalah mengendalikan orang lain dan individu cenderung berorientasi pada diri sendiri. Tingkah laku mengontrol digunakan sebagai pertahanan terhadap kegagalan atau frustasi dan dapat menjadi alat untuk berkuasa pada orang lain.

b. Impulsif

Impulsif merupakan respon sosial yang ditandai dengan individu sebagai subyek yang tidak dapat diduga, tidak dapat dipercaya, tidak mampu merencanakan tidak mampu untuk belajar dari pengalaman dan miskin penilaian.

c. Narsisme

Respon sosial ditandai dengan individu memiliki tingkah laku ogosentris, harga diri yang rapuh, terus menerus berusaha mendapatkan penghargaan dan mudah marah jika tidak mendapat dukungan dari orang lain.

d. Isolasi sosial

Isolasi sosial adalah keadaan dimana seorang individu mengalami penurunan atau bahkan sama sekali tidak mampu berinteraksi dengan orang lain disekitarnya. Pasien mungkin merasa ditolak, tidak diterima, kesepian, dan tidak mampu membina hubungan yang berarti dengan orang lain.

\subsubsection{Etiologi}

Isolasi sosial : menarik diri dapat terjadi dipengaruhi oleh faktor predisposisi dan faktor presipitasi.

a. Faktor predisposisi

Menurut Fitria (2019) faktor predisposisi yang mempengaruhi masalah isolasi sosial yaitu:

1) Faktor tumbuh kembang 
Pada setiap tahap tumbuh kembang terdapat tugas-tugas perkembangan yang harus terpenuhi agar tidak terjadi gangguan dalam hubungan sosial. Apabila tugas tersebut tidak terpenuhi maka akan menghambat fase perkembangan sosial yang nantinya dapat menimbulkan suatu masalah.

Tabel 2.1 Tugas perkembangan berhubungan dengan pertumbuhan interpersonal (Fitria, 2019).

\begin{tabular}{|l|l|}
\hline Tahap perkembangan & Tugas \\
\hline Masa bayi & Menetapkan rasa percaya \\
\hline Masa bermain & $\begin{array}{l}\text { Mengembangkan otonomi dan awal perilaku } \\
\text { mandiri }\end{array}$ \\
\hline Masa prasekolah & $\begin{array}{l}\text { Melajar menunjukan inisiatif, rasa tanggung } \\
\text { jawab, dan hati nurani }\end{array}$ \\
\hline Masa sekolah & $\begin{array}{l}\text { Belajar berkompetisi, bekerja sama, dan } \\
\text { berkompromi }\end{array}$ \\
\hline Masa praremaja & $\begin{array}{l}\text { Menjalin hubungan intim dengan teman sesama } \\
\text { jenis kelamin }\end{array}$ \\
\hline Masa dewasa muda & $\begin{array}{l}\text { Menjadi saling bergantung antara orang tua dan } \\
\text { teman, mencari pasangan, menikah dan } \\
\text { mempunyai anak }\end{array}$ \\
\hline Masa tenga baya & $\begin{array}{l}\text { Belajar menerima hasil kehidupan yang sudah } \\
\text { dilalui }\end{array}$ \\
\hline Masa dewasa tua & $\begin{array}{l}\text { Berduka karena kehilangan dan mengembangkan } \\
\text { perasaan ketertarikan dengan budaya }\end{array}$ \\
\hline
\end{tabular}

2) Faktor komunikasi dalam keluarga

Gangguan komunikasi dalam keluarga merupakan faktor pendukung terjadinya gangguan dalam hubungan sosial. Dalam teori ini yang termasuk masalah dalam berkomunikasi sehingga menimbulkan ketidakjelasan (double bind) yaitu suatu keadaan dimana seorang anggota keluarga menerima pesan yang saling bertentangan dalam waktu bersamaan atau 
ekspresi emosi yang tinggi dalam keluarga yang menghambat untuk hubungan dengan lingkungan diluar keluarga.

3) Faktor sosial budaya

Norma-norma yang salah didalam keluarga atau lingkungan dapat menyebabkan hubungan sosial, dimana setiap anggota keluarga yang tidak produktif seperti lanjut usia, berpenyakit kronis dan penyandang cacat diasingkan dari lingkungan sosialnya.

4) Faktor biologis

Faktor biologis juga merupakan salah satu faktor yang mempengaruhi gangguan dalam hubungan sosial. Organ tubuh yang dapat mempengaruhi gangguan hubungan sosial adalah otak, misalnya pada klien skizofrenia yang mengalami masalah dalam hubungan memiliki struktur yang abnormal pada otak seperti atropi otak, serta perubahan ukuran dan bentuk sel-sel dalam limbic dan daerah kortikal.

\section{b. Faktor presipitasi}

Menurut Herman, (2015), terjadinya gangguan hubungan sosial juga dipengaruhi oleh faktor internal dan eksternal seseorang. Faktor stress orpresipitasi dapat dikelompokan sebagai berikut:

1) Faktor eksternal

Contohnya adalah stressor sosial budaya, yaitu stress yang ditimbulkan oleh faktor sosial budaya seperti keluarga.

2) Faktor internal

Contohnya adalah stressor psikologis, yaitu stress yang terjadi akibat kecemasan atau ansietas yang berkepanjangan dan terjadi bersamaan dengan keterbatasan kemampuan individu untuk mengatasinya. Ansietas ini dapat terjadi akibat tuntutan untuk berpisah dengan orang terdekat atau tidak terpenuhi kebutuhan individu. 


\subsubsection{Penatalaksanaan}

Penatalaksanaan pasien dengan isolasi sosial adalah:

1. Terapi farmakologi

2. Electri Convulsive Therapi Electri Convulsive Therapi (ECT) atau yang dikenal dengan electroshock adalah suatu terapi psikiatri yang menggunakan energy shock listrik dalam usaha pengobatannya. Biasanya ECT ditujukan untuk terapi pasien gangguan jiwa yang tidak berespon kepada obat psikiatri pada dosis terapinya.

3. Terapi Kelompok Terapi kelompok merupakan suatu psikoterapi yang dilakukan sekelompok pasien bersama-sama dengan jalan berdiskusi satu sama lain yang dipimpin atau diarahkan oleh seorang terapis atau petugas kesehatan jiwa. Terapi ini bertujuan memberi stimulus bagi klien dengan gangguan interpersonal.

4. Terapi lingkungan manusia tidak dapat dipisahkan dari lingkungan sehingga aspek lingkungan harus mendapatkan perhatian khusus dalam kaitanya untuk menjaga dan memelihara kesehatan manusia. Lingkungan berkaitan erat dengan stimulus psikologi seseorang yang akan berdampak pada kesembuhan, karena lingkungan tersebut akan memberikan dampak baik pada kondisi fisik maupun kondisi psikologi seseorang.

\subsection{Konsep Asuhan Keperawatan}

\subsubsection{Pengkajian}

Pengkajian merupakan tahap awal dan dasar utama dari proses keperawatan, tahap pengkajian terdiri dari atas pengumpulan data dan perumusan masalah. Data yang dikumpulkan meliputidata biologis, psikologis, sosial, dan spiritual (Hutagalung, 2020). Data pengkajian kesehatan jiwa dapat dikelompokkan menjadi faktor predisposisi, faktor presipitasi, penilaian terhadap stressor, sumber koping, dan kemampuan koping yang dimiliki klien (Hermawan, 2015).

a. Faktor Predisposisi

Menurut Muhith, (2015), Faktor predisposisi antara lain : 
1) Faktor Perkembangan

Pada dasarnya kemampuan seseorang untuk berhubungan sosial berkembang sesuai dengan proses tumbuh kembang. Mulai usia bayi sampai dengan dewasa lanjut untuk dapat mengembangkan hubungan sosial yang positif. Diharapkan setiap tahapan perkembangan dapat dilalui dengan sukses.Sistem keluarga yang tergantung dapat berperan dalam perkembangan respons sosial maladaptif.

Yang paling sering adalah adanya gangguan dalam mencapai tugas perkembangan sehingga individu tidak dapat mengembangkan hubungan yang sehat.

a) Masa bayi : bayi umumnya menggunakan komunikasi yang sangat sederhana dalam menyampaikan kebutuhannya. Karena bayi sangat tergantung pada orang lain dalam pemenuhan kebutuhan biologis dan psikologisnya. Kegagalan pada tahap ini mengakibatkan rasa tidak percaya pada diri sendiri dan orang lain, serta menarik diri.

b) Toodler : mengembangkan otonomi dan awal perilaku mandiri.

c) Pra Sekolah : anak menggunakan kemampuan berhubungan yang telah dimiliki untuk berhubungan dengan lingkungan diluar keluarga. Dalam hal ini, anak membutuhkan dukungan dan bantuan dari keluarga khususnya pemberian positif terhadap perilaku anak yang adaptif. Kegagalan anak dalam berhubungan mengakibatkan anak tidak mampu mengontrol diri, tergantung, ragu, menarik diri dari lingkungan, pesimis.

d) Anak sekolah : pada usia ini anak mulai mengenal bekerjasama, kompetisi, kompromi. Konflik sering terjadi dengan orang tua. Teman dan orang dewasa merupakan sumber pendukung yang penting bagi anak. Kegagalan 
dalam tahap ini mengakibatkan anak menjadi frustasi, putus asa, merasa tidak mampu, dan menarik diri dari lingkungan.

e) Pra remaja : pada usia ini, anak mengembangkan hubungan intim dengan teman sebaya dan teman sejenis maupun lawan jenis.Kegagalan membina hubungan dengan teman dan kurangnya dukungan orang tua akan mengakibatkan keraguan akan identitas dan rasa percaya diri yang kurang.

f) Dewasa muda : individu belajar mengambil keputusan dengan memperhatikan saran dan pendapat orang lain seperti memilih pekerjaan, karir, melangsungkan pernikahan.Kegagalan pada tahap ini mengakibatkan individu menghindari hubungan intim, menjauhi orang lain, putus asa akan karir.

g) Dewasa tengah : individu pada usia dewasa tengah umumnya telah menikah. Individu yang perkembangannya baik akan dapat mengembangkan hubungan dan dukungan yang baru.Kegagalan pada tahap ini mengakibatkan perhatian hanya tertuju pada dirinya sendiri, produktivitas dan kreatifitas berkurang, dan perhatian terhadap orang lain berkurang.

h) Dewasa lanjut : individu tetap memerlukan hubungan yang memuaskan dengan orang lain. Kegagalan pada tahap ini mengakibatkan perilaku menarik diri.

2) Faktor Biologis

Menurut Gaol, (2021), Faktor genetik dapat berperan dalam respons sosial maladaptif. Terjadinya penyakit jiwa pada individu juga dipengaruhi oleh keluarganya dibanding dengan individu yang tidak mempunyai riwayat penyakit terkait.

3) Faktor Sosiokultural 
Menurut Hasriana, Nur \& Anggraini, (2013) Isolasi sosial merupakan faktor utama dalam gangguan hubungan. Hal ini akibat dari transiensi: norma yang tidak mendukung pendekatan terhadap orang lain atau tidak menghargai anggota masyarakat yang kurang produkstif seperti lanjut usia (lansia), orang cacat, penderita kronis. Isolasi dapat terjadi karena mengadopsi norma, perilaku, dan system nilai yang berbeda dari yang dimiliki budaya mayoritas.

4) Faktor Dalam Keluarga

Menurut Puspitawati, (2020) Pola komunikasi dalam keluarga dapat mengantar seseorang dalam gangguan berhubungan, bila keluarga hanya mengiformasikan hal - hal yang negatif akan mendorong anak mengembangkan harga diri rendah. Adanya dua pesan yang bertentangan disampaikan pada saat yang bersamaan, mengakibatkan anak menjadi traumatik dan enggan berkomunikasi dengan orang lain.

b. Faktor Presipitasi

Menurut Puspitawati, (2020) faktor presipitasi terdiri dari :

1) Stre ssor Sosiokultural

Stres dapat ditimbulkan oleh menurunnya stabilitas unit keluarga dan berpisah dari orang yang berarti, misalnya karena dirawat di rumah sakit.

2) Stresor Psikologis

Ansietas berat yang berkepanjangan terjadi bersamaan dengan keterbatasan kemampuan untuk mengatasinya. Tuntutan untuk berpisah dengan orang terdekat atau kegagalan orang lain untuk memenuhi kebutuhan ketergantungan dapat menimbulkan ansietas tingkat tinggi.

c. Manifestasi Klinis

Menurut Sumarno, (2019) observasi yang dilakukan pada klien dengan isolasi sosial akan ditemukan data objektif meliputi apatis, ekspresi wajah sedih, afek tumpul, menghindar dari 
orang lain, klien tampak memisahkan diri dari orang lain, komunikasi kurang, klien tampak tidak bercakap-cakap dengan klien orang lain, tidak ada kontak mata atau kontak mata kurang, klien lebih sering menunduk, berdiam diri di kamar klien. Menolak berhubungan dengan orang lain, tidak melakukan kegiatan sehari-hari, meniru posisi janin pada saat tidur. Sedangkan untuk data subjektif sukar didapat jika klien menolak komunikasi. Beberapa data subjektif adalah menjawab dengan singkat, dengan kata-kata " tidak", "ya", dan "tidak tahu".

d. Mekanisme Koping

Individu yang mengalami respon sosial maladaptif, menggunakan berbagai mekanisme dalam upaya mengatasi ansietas. Mekanisme tersebut berkaitan dengan dua jenis masalah hubungan yang spesifik. Koping yang berhubungan dengan gangguan kepribadian anti sosial antara lain : proyeksi, merendahkan orang lain. Koping ini berhubungan dengan gangguan kepribadian ambang : formasi reaksi, isolasi, idelisasi orang lain dan merendahkan orang lain (Banjar, 2016).

e. Sumber Koping

Sumber koping berhubungan dengan respon sosial maladaptif meliputi : keterlibatan dalam hubungan keluarga yang luas dan teman (Banjar, 2016).

\subsubsection{Diagnosa Keperawatan}

Menurut Sutejo (2017) adapun daftar masalah keperawatan pada klien dengan isolasi sosial sebagai berikut:

1. Isolasi Sosial

2. Gangguan konsep diri: harga diri rendah

3. Resiko gangguan sensori persepsi: halusinasi

\subsubsection{Perencanaan Keperawatan}

1. Perencanaan keperawatan 
Perencanaan keperawatan merupakan serangkaian tindakan yang dapat mencapai setiap tujuan khusus. Perawat dapat memberikan alasan il miah terbaru dari tindakan yang diberikan. Alasan ilmiah merupakan pengetahuan yang berdasarkan pada literatur, hasil penelitian atau pengalaman praktek (Haebahan, 2020).

2. Penatalaksanaan Medis

Jenis penatalaksanaan yang biasa dilakukan dalam kelompok penyakit skizofrenia termasuk isolasi sosial adalah (Ayuningtyas, 2020) :

a) Psikofarmaka

Adalah terapi dengan menggunakan obat, tujuannya untuk mengurangi atau menghilangkan gejala-gejala gangguan jiwa. Yang tergolong dalam pengobatan psikofarmaka antara lain :

1) Chlorpromazine (CPZ)

Atas indikasi untuk sindrom psikosis yaitu berdaya berat untuk menilai realistis, waham halusinasi, gangguan perasaan dan perilaku atau tidak terkendali tidak mampu bekerja. Dengan efek samping hipotesis, epilepsy, kelainan jantung, febris, ketergantungan obat.

2) Haloperidol (HLP)

Atas indikasi berdaya berat dalam kemampuan menilai realita dalam fungsi mental serta dalam fungsi kehidupan sehari-hari dengan efek samping yaitu : penyakit hati, penyakit darah (anemia, leucopenia, agranulositosis), epilepsy, kelainan jantung, febris, dan ketergantungan obat.

3) Tryhexipenidil (THP)

Atas indikasi segala jenis perkinson, termasuk pasca encephalitis dengan efek samping yaitu mulut kering, penglihatan kabur, pusing, mual, muntah, bingung, agitasi, konstipasi, takikardia, dilatasi, ginjal, retensi urin. 
Kontra indikasinya yaitu hipersensitif terhadap tryhexipenidil, glukosa sudut sempit, hipertropi prostate dan obstruksi saluran cerna.

b) Pemeriksaan Penunjang (ECT / Psikotherapy)

Menurut Astuti, (2020) merupakan pengobatan untuk menurunkan kejang grandial yang menghasilkan efek samping tetapi dengan menggunakan arus listrik. Tujuan untuk memperpendek lamanya skizofrenia dan dapat mempermudah kontak dengan orang lain. Dengan kekuatan 75 - 100 volt, ECT diberikan pada klien dengan indikasi depresi berat dan terapi obat sebelumnya tidak berhasil, klien akan beresiko bunuh diri dan skizofrenia akut.

c) Prinsip Keperawatan

Menurut Siskayanti, (2012) menerapkan teknik therapeutik, melibatkan keluarga, kontak sering tetapi singkat, peduli, empati, jujur, menepati janji, memenuhi kebutuhan sehari hari, libatkan klien TAK.

1) Pelaksanaan Keperawatan

Pelaksanana tindakan keperawatan merupakan langkah keempat dari proses keperawatan. Dan disesuaikan dengan rencana tindakan keperawatan. Sebelum melaksanakan tindakan keperawatan yang sudah direncanakan, perawat perlu memvalidasi dengan singkat, apakah rencana tindakan masih sesuai dan dibutuhkan oleh klien saat ini (here and now) (Keliat, 2005). Jenis tindakannya seperti :

1. Secara mandiri (independent)

Adalah tindakan yang diprakarsai sendiri oleh perawat untuk membantu klien dalam mengatasi masalahnya atau menanggapi reaksi karena adanya stressor (penyakit). Misalnya ; membantu klien dalam melakukan kegiatan sehari - hari, memberikan dorongan pada klien untuk mengungkapkan 
perasaannya secara wajar, menciptakan lingkungan terapeutik.

2. Saling ketergantungan atau kolaborasi ( interdependen) Adalah tindakan keperawatan atas dasar kerjasama sesama tim perawatan atau dengan tim kesehatan lainnya. Seperti dokter, fisioterapi, analis kesehatan, dan sebagainya. Misalnya ; pemberian obat - obatan sesuai dengan intruksi dokter. Jenis dosis dan efek samping menjadi tanggung jawab dokter tetapi pemberian obat sampai atau tidak menjadi tanggung jawab.

3. Rujukan atau ketergantungan (dependen)

Adalah tindakan keperawatan atas dasar rujukan dari profesi lain, diantaranya: dokter, psikologi, pskiater, ahli gizi, fisioterapi. Misalnya; terapi aktivitas kelompok.

\subsubsection{Evaluasi Keperawatan}

Evaluasi adalah proses berkelanjutan untuk menilai efek dari tindakan keperawatan pada klien. Evaluasi dilakukan terus- menerus pada respons klien terhadap tindakan keperawatan yang dilaksanakan. Hasil yang diharapkan pada klien, yaitu: klien dapat membina hubungan saling percaya dengan orang lain, klien dapat menyebutkan penyebab menarik diri, klien dapat menyebutkan keuntungan berhubungan sosial, klien dapat melaksanakan hubungan sosial, klien mampu menjelaskan perasaannya setelah berhubungan sosial dengan orang lain, kelompok. Klien mendapat dukungan keluarga dalam memperluas hubungan sosial, klien dapat memanfaatkan obat (Rahmadani, 2019). 


\section{BAB 3 \\ TINJAUAN KASUS}

\subsection{Identitas Klien}

$\begin{array}{ll}\text { Inisial } & : \text { Tn.S } \\ \text { Jenis kelamin } & : \text { Laki-Laki } \\ \text { Umur } & : \text { Tahun } \\ \text { Agama } & : \text { Budha } \\ \text { Status } & : \text { Lajang } \\ \text { Tanggal pengkajian } & : \text { Maret } 2021 \\ \text { Informant } & : \text { Status klien dan komunikasi dengan klien. }\end{array}$

\subsection{Alasan Masuk ke Yayasan pemenang jiwa}

Klien sering menyendiri, bicara sendiri, bingung, sulit tidur, tidak mau makan, jarang sekali bergaul dengan lingkungan, karena klien merasa malu dan juga merasa dirinya dimusuhi oleh adik kandungnya hingga akhirnya klien memukul adik kandungnya, terkadang klien juga marah-marah dan berteriak jika dipaksa untuk makan dan minum

\subsection{Faktor Predisposisi}

Klien mengatakan merasa terpukul ketika ibunya meninggal, klien mengatakan bapak dan saudara - saudaranya tidak mempedulikannya. Dirumah klien selalu mengurung diri dikamar, tidak mau berkomunikasi dengan keluarga, tidak pernah mandi, sehingga timbul gejala-gejala seperti diatas. Keluarga klien tidak ada yang pernah mengalami gangguan jiwa. Masalah Keperawatan : Isolasi Sosial

\subsection{Fisik}

Klien tidak memiliki keluhan fisik, saat dilakukan pemeriksaan tanda-tanda vital, didapatkan hasil TD : 120/80 mmHg ; N : 80x/i ; S : 35, $5^{\circ} \mathrm{C} ; \mathrm{P}: 20 \mathrm{x} / \mathrm{i}$. Klien memiliki tinggi badan $165 \mathrm{~cm}$ dan berat badan $68 \mathrm{Kg}$. 


\subsection{Psikososial}

\subsubsection{Genogram}

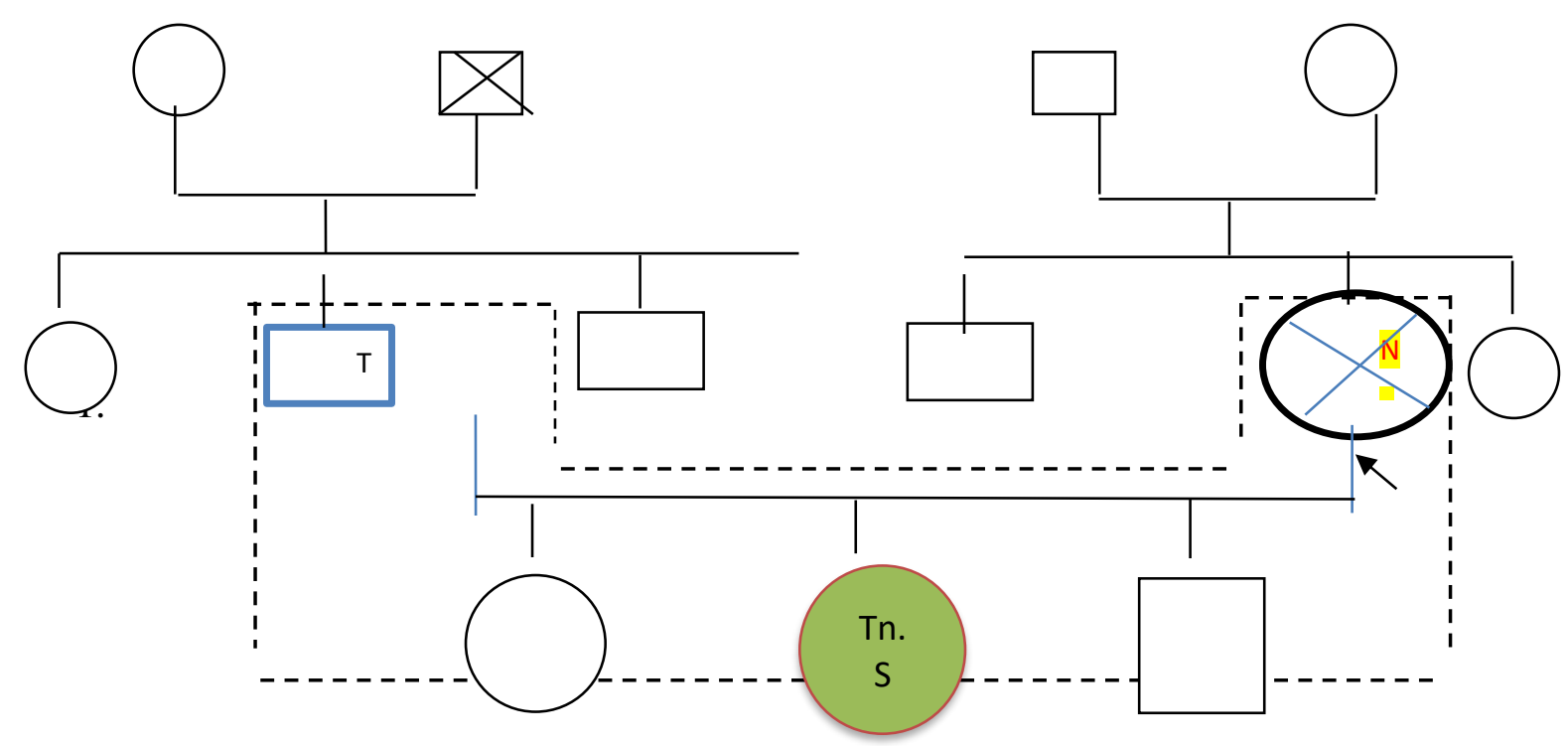

Penjelasan :

Klien anak kedua dari 3 bersaudara, klien berinisial Tn.S, anak piatu ibunya meninggal saat usia klien 25 tahun.

Keterangan :

$\square$ : Perempuan

$\bigcirc$ : Laki-Laki

Tn.S : Klien

---- : Tinggal dalam satu rumah

$\searrow$ : Meninggal

\subsubsection{Konsep Diri}

a. Gambaran diri: Tidak ada kecacatan

b. Identitas : Klien anak ke 2 dari 3 bersaudara, klien hanya lulusan SMA yang saat ini dirawat di Yayasan Pemenang Jiwa Medan

c. Peran : Klien berperan sebagai anak dan masih lajang, klien sebelunya tinggal bersama keluarganya.. 
d. Ideal diri : Klien merasa takut karena di antarkan ke yayasan pemenangan jiwa ingin cepat pulang kerumah

e. Harga diri : Klien merasa malu dirawat di yayasan pemenangan jiwa dan merasa bosan

\subsubsection{Hubungan Sosial}

Klien mengganggap bahwa keluarganya adalah orang yang sangat berarti dalam hidupnya, terutama ibunya yang sudah meninggal. Klien selalu mengikuti kegiatan di yayasan tersebut. Klien mengatakan tidak pernah bersosialisasi dengan teman teman di yayasan, dan tidak mau mempunyai teman dan ingin sendiri, klien tidak suka bergaul bergaul Masalah keperawatan: Isolasi Sosial

\subsubsection{Spiritual}

a. Nilai dan Keyakinan :Klien beragama Budha dan yakin dengan agamanya.

b. Kegiatan Ibadah :Ibadah 3 kali sehari, yaitu pagi 2 kali, sekitar pukul 6 pagi dan pukul 10 pagi, selanjutnya jam 7 malam.

\subsubsection{Status Mental}

a. Penampilan

Klien berpenampilan bersih, dan rapi

b. Pembicaraan

Klien masih mampu menjawab pertanyaan perawat dengan lambat namun dapat dipahami

c. Aktivitas Motorik

Klien terlihat diam, menundukkan kepala

d. Suasana perasaan

Klien sedih jika mengingat orang tua yang tidak mempedulikannya dan mengingat ibunya yang sudah meninggal.

Masalah keperawatan : Harga Diri Rendah 
e. Afek

Afek klien labil, mudah emosi, mudah marah pada saat meminta makan untuk makan.

Masalah keperawatan : Risiko perilaku kekerasan

f. Interaksi selama wawancara

Klien kooperatif, tidak ada kontak mata pada lawan bicara, tidak mudah tersinggung dalam setiap interaksi.

g. Persepsi

Klien sering mendengar suara-suara tampa wajah yang menyuruhnya untuk beribadah.

Masalah keperawatan : gangguan persepsi sensori: Halusinasi

h. Proses Pikir

Klien mampu menjawab apa yang ditanya dengan baik.

i. Isi pikir

Klien dapat mengontrol isi pikirnya,klien tidak mengalami gangguan isi pikir dan tidak ada waham. Klien tidak

j. Tingkat kesadaran

Klien tidak mengalami gangguan orientasi, klien mengenali waktu, orang dan tempat.

k. Memori

Klien mampu menceritakan kejadian di masa lalu dan yang baru terjadi.

i. Tingkat konsentrasi berhitung

Klien mampu berkonsentrasi dalam perhitungan sederhana tanpa bantuan orang lain.

j. Kemampuan penilaian

Klien dapat membedakan hal yang baik dan yang buruk.

k. Daya tilik diri

Klien tidak mengetahui penyakit yang dideritanya, klien mengetahui bahwa dia sering menyendiri dan tidak suka bersosialisasi. 


\subsection{Mekanisme Koping}

Klien mengalami mekanisme koping yaitu klien tidak dapat berbicara baik dengan orang lain.

\subsection{Masalah Psikososial dan Lingkungan}

Masalah dengan dukungan kelompok, spesifik: pasien mengatakan dukungan psikososial dan lingkungan di yayasan sangat baik, hanya saja lebih suka menyendiri dan tidak suka bersosialisasi

Masalah keperawatan: Isolasi Sosial.

\subsection{Pengetahuan Kurang Tentang Gangguan Jiwa}

Klien tidak mengetahui tentang gangguan jiwa yang di alaminya dan klien tidak tau apa obat yang dikonsumsinya.

\subsection{Analisis Data}

\begin{tabular}{|c|c|c|}
\hline No & Data & Masalah Keperawatan \\
\hline 1 & $\begin{array}{l}\text { Subjektif: } \\
\text { Klien sering menyendiri, bicara sendiri, } \\
\text { bingung, sulit tidur, tidak mau makan, } \\
\text { jarang sekali bergaul dengan lingkungan, } \\
\text { karena klien merasa malu dan juga merasa } \\
\text { dirinya dimusuhi oleh adik kandungnya } \\
\text { hingga akhirnya klien memukul adik } \\
\text { kandungnya, terkadang klien juga marah- } \\
\text { marah dan berteriak jika dipaksa untuk } \\
\text { makan dan minum } \\
\text { Objektif: } \\
\text { Sering terlihat melamun, klien tampak } \\
\text { bingung dan bicara sendiri, klien kurang } \\
\text { kooperatif, menundukan kepala saat } \\
\text { wawancara, dan pendiam dan suka } \\
\text { menyendiri, Klien tampak menghindari }\end{array}$ & Isolasi Sosial \\
\hline
\end{tabular}




\begin{tabular}{|l|lr|l|}
\hline $\begin{array}{l}\text { interaksi, terlihat sedih, pendangan } \\
\text { menunduk kebawah dan klien tidak } \\
\text { mempunyai teman. }\end{array}$ & \\
\hline
\end{tabular}




\begin{tabular}{|c|c|c|}
\hline 2 & $\begin{array}{l}\text { Subjektif: } \\
\text { Klien mengatakan malu dan malas } \\
\text { berinteraksi dengan orang lain, klien } \\
\text { merasa dibuang oleh keluarganya, } \\
\text { malu karena tidak mempunyai } \\
\text { pekerjaan dan penghasilan sendiri, } \\
\text { klien memilih memendam masalahnya } \\
\text { sendiri, } \\
\text { Objektif: } \\
\text { Klien tampak lemah dan tidak } \\
\text { bersemangat, kontak mata kurang, } \\
\text { klien lebih sering menyendiri. }\end{array}$ & Harga Diri Rendah \\
\hline 3 & $\begin{array}{l}\text { Subjektif: } \\
\text { Klien mengatakan merasa malu dan } \\
\text { juga merasa dirinya dimusuhi oleh } \\
\text { adik kandungnya, hingga akhirnya } \\
\text { klien memukul adik kandungnya } \\
\text { Objektif : } \\
\text { Klien tampak marah-marah dan } \\
\text { berteriak jika dipaksa untuk makan dan } \\
\text { minum }\end{array}$ & $\begin{array}{c}\text { Resiko Perilaku } \\
\text { Kekerasan }\end{array}$ \\
\hline 4 & $\begin{array}{l}\text { Subjektif: } \\
\text { Keluarga klien mengatakan bahwa } \\
\text { klien sering berteriak Klien sering } \\
\text { mendengarkan suara - suara tampa } \\
\text { wajah yang menyuruhnya untuk selalu } \\
\text { ibadah. Klien mengatakan suara - } \\
\text { suara tersebut muncul } 3 \text { kali / hari, } \\
\text { muncul pada saat klien sedang } \\
\text { menyendiri Klien merasa gelisah dan } \\
\text { takut jika mendengar suara tersebut }\end{array}$ & $\begin{array}{l}\text { Gangguan } \\
\text { sensori : } \\
\text { pendengaran }\end{array}$ \\
\hline
\end{tabular}




\begin{tabular}{|l|l|}
\hline Objektif : & \\
Klien sering marah - marah, mondar - & \\
mandir, bicara sendiri, bicara ngawur, & \\
sering senyum - senyum sendiri & \\
\hline
\end{tabular}

\subsection{Pohon Masalah}

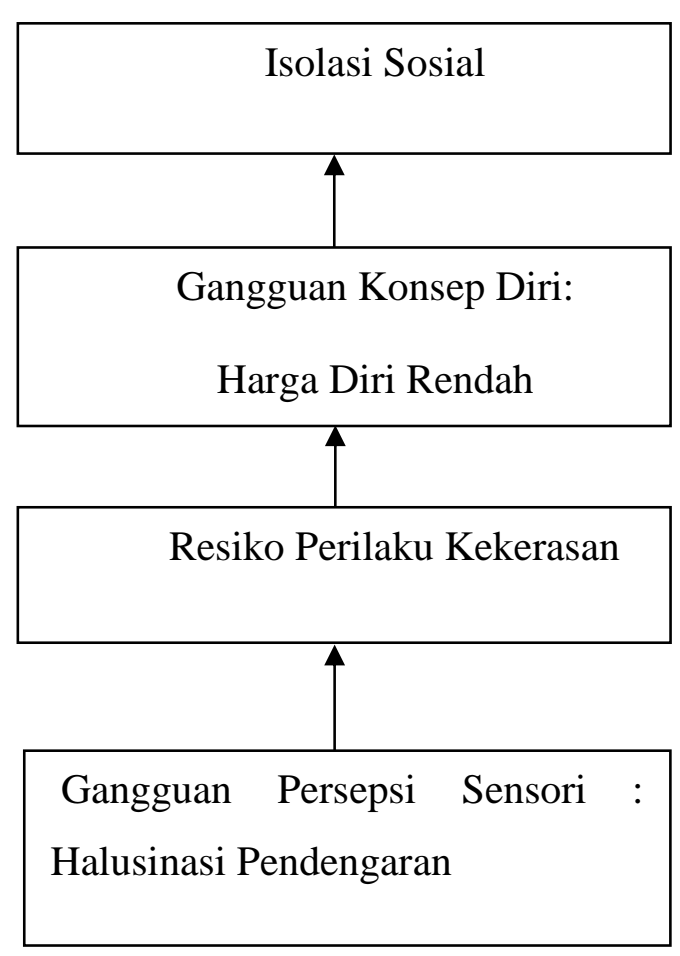

\subsection{Diagnosa Keperawatan}
a. Isolasi Sosial
b. Gangguan Konsep Diri : Harga Diri Rendah
c. Resiko Perilaku Kekerasan
d. Gangguan Persepsi Sensori : Halusinasi Pendengaran 
3.12 Intervensi Keperawatan

\begin{tabular}{|c|c|c|c|}
\hline Diagnosa & Tujuan & Kriteria Hasil & Intervensi \\
\hline Isolasi Sosial & 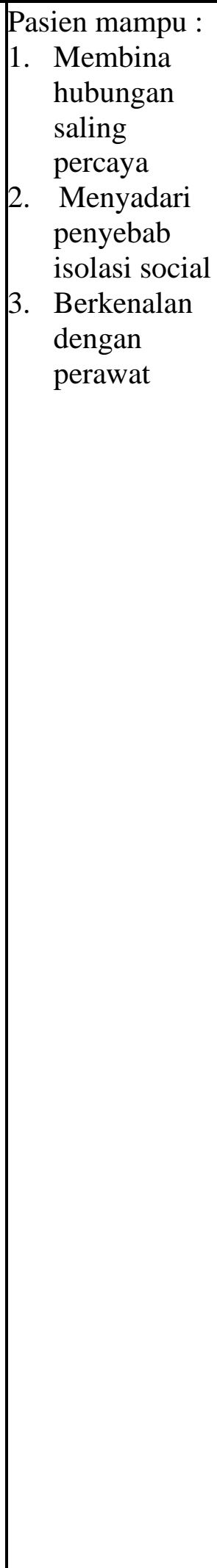 & 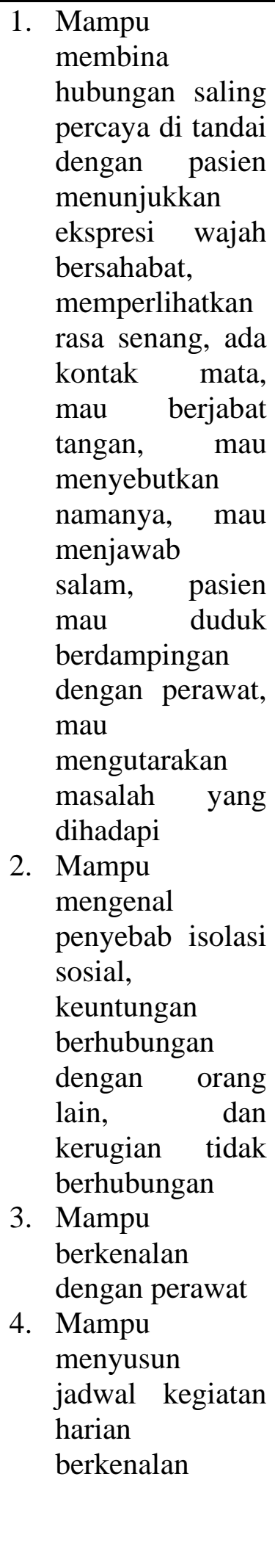 & 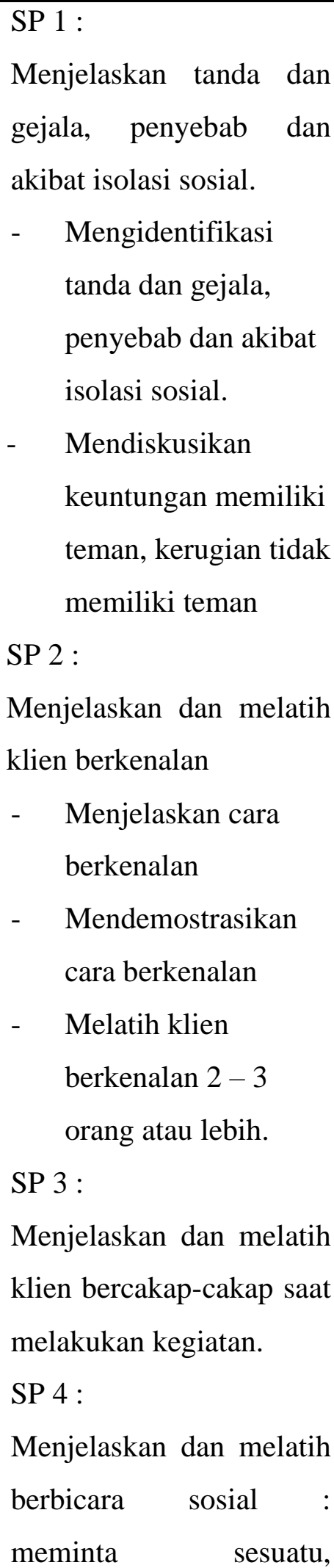 \\
\hline
\end{tabular}




\begin{tabular}{|c|c|c|c|}
\hline & & & $\begin{array}{l}\text { berbelanja dan lain } \\
\text { sebagainya. }\end{array}$ \\
\hline $\begin{array}{c}\text { Harga Diri } \\
\text { Rendah } \\
\text { Kronis }\end{array}$ & 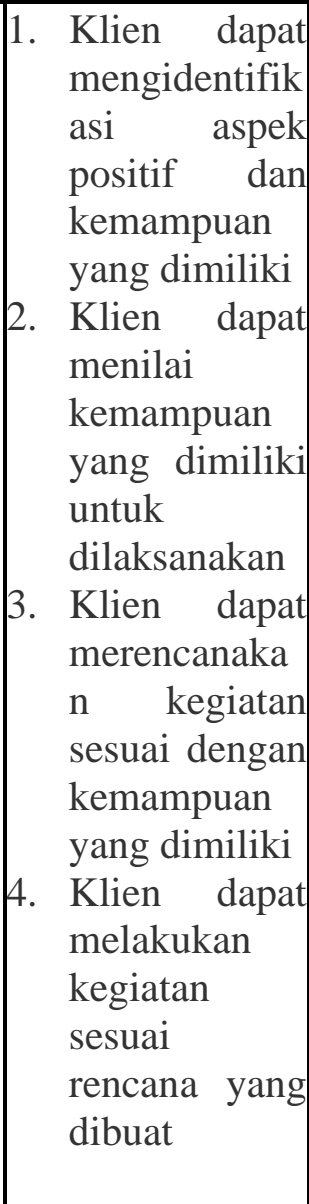 & $\begin{array}{l}\text { 1. Mampu } \\
\text { mengidentifikasi } \\
\text { aspek positif dan } \\
\text { kemampuan } \\
\text { yang dimiliki } \\
\text { 2. Klien mampu } \\
\text { menilai } \\
\text { kemampuan } \\
\text { yang dimiliki } \\
\text { untuk dilaksanakan } \\
\text { dilapat } \\
\text { 3. Klien desuai } \\
\text { merencanakan } \\
\text { kegiatan san dapat } \\
\text { dengan sesuai } \\
\text { kemampuan } \\
\text { yang dimiliki } \\
\text { 4. Klien yang } \\
\text { melakukan } \\
\text { kegiatan san } \\
\text { rencana } \\
\text { dibuat }\end{array}$ & $\begin{array}{l}\text { Sp 1 : Mengidentifikasi } \\
\text { kemampuan dan aspek } \\
\text { positif yang dimiliki } \\
\text { pasien } \\
\text { Sp 2: } \\
\text { a. } \\
\text { Menilai } \\
\text { kemampuan yang } \\
\text { dapat digunakan } \\
\text { b. } \\
\text { Menetapkan atau } \\
\text { memilih kegiatan } \\
\text { sesuai } \\
\text { kemampuan } \\
\text { c. } \\
\text { Melatih kegiatan } \\
\text { sesuai } \\
\text { kemampuan yang } \\
\text { dipilih } 1 \\
\text { Sp } 3 \text { : Melatih kegiatan } \\
\text { sesuai kemampuan yang } \\
\text { dipilih } 2 \\
\text { Sp } 4 \text { : Melatih kegiatan } \\
\text { sesuai kemampuan yang } \\
\text { dipilih } 3\end{array}$ \\
\hline $\begin{array}{c}\text { Resiko } \\
\text { Perilaku } \\
\text { Kekerasan }\end{array}$ & $\begin{array}{l}\text { Klien dapat } \\
\text { mebina } \\
\text { hubungan } \\
\text { saling percaya }\end{array}$ & $\begin{array}{l}\text { Ketika di } \\
\text { evaluasi Klien } \\
\text { mau membalas } \\
\text { salam, berjabat } \\
\text { tangan, } \\
\text { menyebutkan } \\
\text { nama, } \\
\text { tersenyum, ada } \\
\text { kontak mata, } \\
\text { serta } \\
\text { menyediakan } \\
\text { waktu untuk } \\
\text { kunjungan } \\
\text { berikutnya }\end{array}$ & $\begin{array}{l}\text { 1.1. Membina } \\
\text { hubungan saling } \\
\text { percaya dengan } \\
\text { cara } \\
\text { (menjelaskan } \\
\text { maksud dan } \\
\text { tujuan interaksi, } \\
\text { jelaskan tentang } \\
\text { kontrak yang akan } \\
\text { dibuat, beri rasa } \\
\text { aman dan sikap } \\
\text { empati) } \\
\text { 1.2. Diskusikan } \\
\text { bersama klien } \\
\text { tentang perilaku } \\
\text { kekerasan } \\
\text { (penyebab, tanda } \\
\text { dan gejala, perilaku } \\
\text { yang muncul dan }\end{array}$ \\
\hline
\end{tabular}




\begin{tabular}{|c|c|c|c|}
\hline & & & $\begin{array}{l}\text { akibat dari perilaku } \\
\text { tersebut). }\end{array}$ \\
\hline $\begin{array}{c}\text { Gangguan } \\
\text { Persepsi } \\
\text { Sensori : } \\
\text { Halusinasi } \\
\text { Pendengaran }\end{array}$ & $\begin{array}{l}\text { Klien mampu } \\
\text { mengontrol } \\
\text { halusinasi }\end{array}$ & 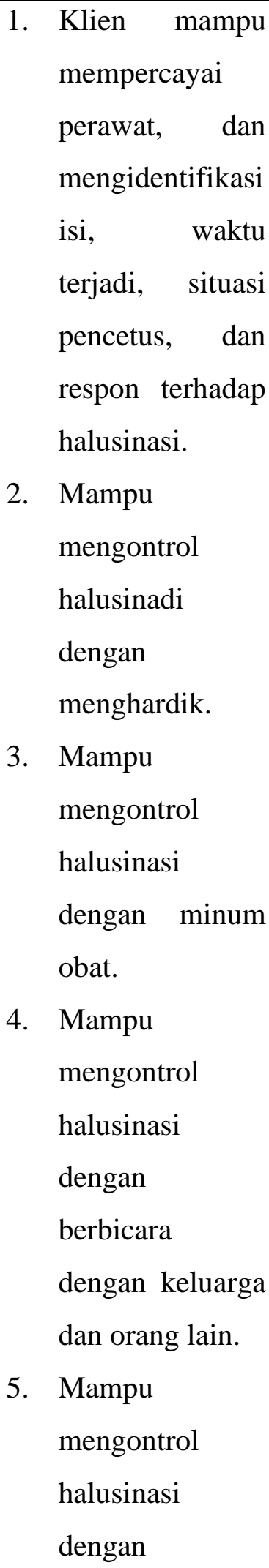 & $\begin{array}{l}\text { SP 1: } \\
\text { 1. Identifikasi isi, waktu } \\
\text { terjadi, situasi } \\
\text { pencetus, dan respon } \\
\text { terhadap halusinasi } \\
\text { 2. Mengontrol } \\
\text { halusinasi dengan } \\
\text { cara menghardik } \\
\text { SP 2: } \\
\text { Mengontrol } \\
\text { Halusinasi dengan } \\
\text { cara minum obat } \\
\text { secara teratur } \\
\text { SP 3: } \\
\text { Mengontrol halusinasi } \\
\text { dengan cara bercakap } \\
\text { - cakap dengan orang } \\
\text { lain } \\
\text { mengontrol halusinasi } \\
\text { dengan } \\
\text { melakukan aktifitas } \\
\text { te }\end{array}$ \\
\hline
\end{tabular}




\begin{tabular}{|l|l|l|l|}
\hline & melakukan & \\
& & kegiatan & \\
terjadwal. & \\
& & & \\
\hline
\end{tabular}

\subsection{Implementasi dan Evaluasi Keperawatan}

\begin{tabular}{|c|c|c|}
\hline Waktu & Implementasi & Evaluasi \\
\hline $\begin{array}{l}\text { Senin, } 8 \\
\text { Maret } 2021 \\
\text { Jam 10: } 45 \\
\text { wib }\end{array}$ & $\begin{array}{l}\text { 2. Diagnosa Keperawatan } \\
\text { Isolasi Sosial } \\
\text { 3. Tindakan Keperawatan } \\
\text { Sp1 Isolasi Sosial } \\
\text { Menjelaskan Tanda dan } \\
\text { gejala, penyebab dan } \\
\text { akibat isolasi sosial. } \\
\text { - Mengidentifikasi tanda } \\
\text { dan gejala, penyebab } \\
\text { dan akibat isolasi } \\
\text { sosial. } \\
\text { - Mendiskusikan } \\
\text { keuntungan memiliki } \\
\text { teman, kerugian tidak }\end{array}$ & $\begin{array}{l}\text { S Lebih banyak diam, } \\
\text { pandangan } \\
\text { kebawah } \\
\text { O : } \\
\text { - } \begin{array}{l}\text { Pasien belum } \\
\text { mengenali masalah isolasi }\end{array} \\
\text { sosial dengan mandiri. } \\
\text { Mengidentifikasi } \\
\text { sosialnya; tanda dan gejala, } \\
\text { penyebab dan akibat dari } \\
\text { isolasi sosial } \\
\text { Pasien belum } \\
\text { menjelaskan mampu } \\
\text { memiliki teman dan kerugian } \\
\text { memiliki teman dengan } \\
\text { mandiri. }\end{array}$ \\
\hline
\end{tabular}




\begin{tabular}{|c|c|c|}
\hline & $\begin{array}{l}\text { memiliki teman } \\
\text { 4. } \underline{\text { RTL }} \\
\text { Sp } 2 \text { : } \\
\text { Menjelaskan dan melatih } \\
\text { klien berkenalan } \\
\text { - } \quad \text { Menjelaskan cara } \\
\text { berkenalan } \\
\text { - Mendemostrasikan cara } \\
\text { berkenalan Melatih } \\
\text { klien berkenalan } 2 \text { dan } \\
\text { 3 orang atau lebih. }\end{array}$ & $\begin{array}{l}\text { dari isolasi sosial } \\
\text { - Menjelaskan Keuntungan } \\
\text { memiliki teman dan kerugian } \\
\text { memiliki teman. }\end{array}$ \\
\hline $\begin{array}{l}\text { Rabu, } 10 \\
\text { Maret } 2021 \\
\text { Jam 10: } 45 \\
\text { wib }\end{array}$ & $\begin{array}{l}\text { 1. Data } \\
\text { Sering terlihat melamun, } \\
\text { klien tampak bingung } \\
\text { dan bicara sendiri, tidak } \\
\text { mempunya teman. Klien } \\
\text { kurang kooperatif, } \\
\text { menundukan kepala saat } \\
\text { wawancara, dan pendiam } \\
\text { dan suka menyendiri, } \\
\text { Klien tampak } \\
\text { menghindari interaksi, } \\
\text { terlihat sedih, } \\
\text { 2. Diagnosa keperawatan } \\
\text { - Isolasi Sosial } \\
\text { 3. Tindakan keperawatan } \\
\text { Sp } 2 \text { : Menjelaskan dan } \\
\text { melatih } \\
\text { berkenalan } \\
\text { - Menjelaskan cara } \\
\text { berkenalan Mendemostrasikan cara }\end{array}$ & 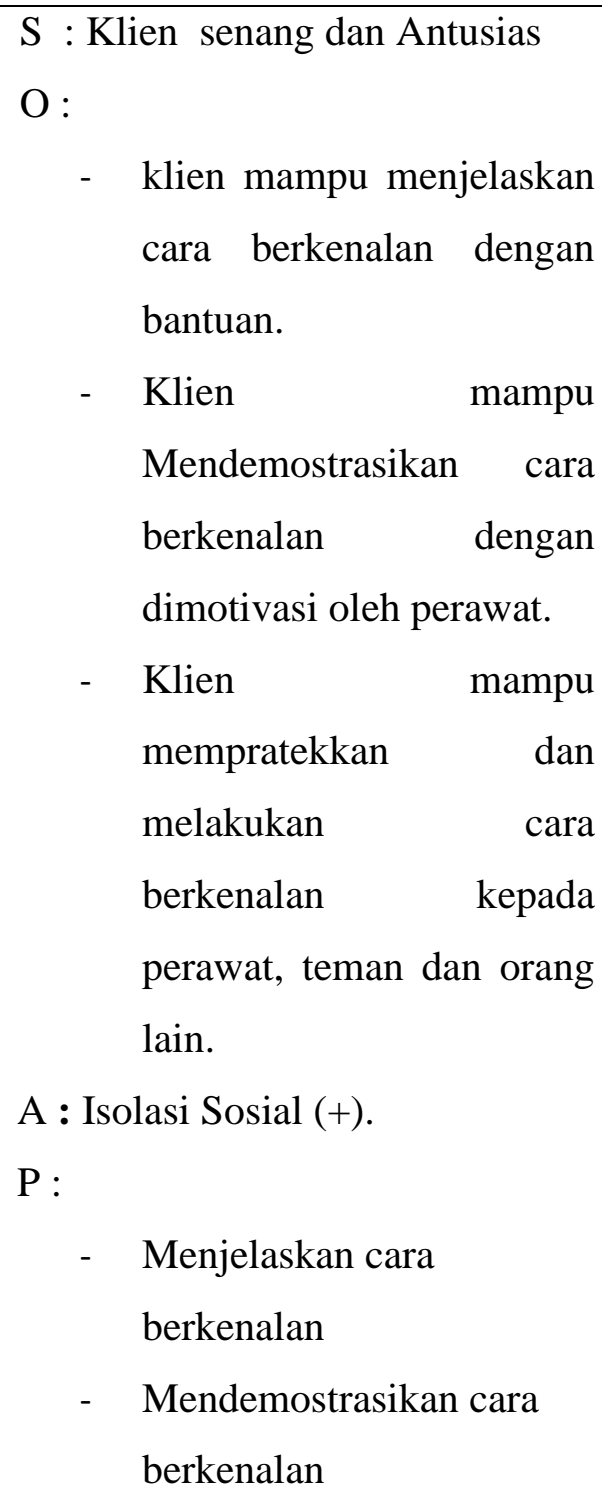 \\
\hline
\end{tabular}




\begin{tabular}{|c|c|c|}
\hline & $\begin{array}{l}\text { berkenalan } \\
\text { - Melatih klien } \\
\text { berkenalan } 2 \text { - } 3 \text { orang } \\
\text { atau lebih. } \\
\text { RTL : } \\
\text { SP 3 : } \\
\text { Menjelaskan dan melatih } \\
\text { klien bercakap- cakap saat } \\
\text { melakukan kegiatan. } \\
\text { SP } 4 \text { : } \\
\text { Menjelaskan dan } \\
\text { melatih berbicara sosia; } \\
\text { : meminta sesuatu, } \\
\text { berbelanja dan lain } \\
\text { sebagainya. }\end{array}$ & $\begin{array}{l}\text { Latih klien berkenalan } \\
\text { dengan satu orang, dua } \\
\text { orang, tiga orang atau } \\
\text { lebih } 3 x / \text { hari }\end{array}$ \\
\hline $\begin{array}{l}\text { Rabu, } 17 \\
\text { Maret 2020 } \\
\text { Jam 10:00 } \\
\text { wib }\end{array}$ & $\begin{array}{l}\text { 1. Data } \\
\text { klien tampak bingung } \\
\text { dan bicara sendiri, tidak } \\
\text { mempunya teman. Klien } \\
\text { kurang kooperatif, } \\
\text { menundukan kepala saat } \\
\text { wawancara, dan pendiam } \\
\text { dan suka menyendiri, } \\
\text { Klien tampak } \\
\text { menghindari interaksi, } \\
\text { terlihat sedih, }\end{array}$ & $\begin{array}{l}\text { S : Klien mengatakan dia merasa } \\
\text { senang bisa bercakap-cakap } \\
\text { dengan orang lain } \\
\text { O : Klien mampu mempraktekkan } \\
\text { cara bercakap-cakap dengan } \\
\text { orang lain saat melakukan } \\
\text { kegiatan dengan mandiri. } \\
\text { - Klien mampu } \\
\text { bersosialisasi meminta } \\
\text { sesuatu dengan mandiri. } \\
\text { A : Isolasi Sosial (-) } \\
\text { P : Intervensi dilanjutkan } \\
\text { - Latihan bercakap cakap } \\
\text { sambil melakukan kegiatan } \\
\text { harian } 3 \text { x/ hari } \\
\text { Latihan berbicara sosial }\end{array}$ \\
\hline
\end{tabular}




\begin{tabular}{|c|c|c|}
\hline & $\begin{array}{l}\text { klien bercakap- cakap saat } \\
\text { melakukan kegiatan. } \\
\text { SP } 4 \text { : } \\
\text { Menjelaskan dan melatih } \\
\text { berbicara sosial; : meminta } \\
\text { sesuatu, berbelanja dan lain } \\
\text { sebagainya. } \\
\text { RTL : } \\
\text { Isolasi Sosial ; : Follow up } \\
\text { dan evaluasi Sp 1-4 Isolasi } \\
\text { sosial }\end{array}$ & $\begin{array}{l}\text { meminta sesuatu } 3 \mathrm{x} / \mathrm{hari} \\
\text { - } \quad \text { Latihan bercakap-cakap } \\
\text { dengan orang lain } 3 \mathrm{x} / \text { hari }\end{array}$ \\
\hline
\end{tabular}

\begin{tabular}{|c|c|c|}
\hline Hari/tgl & Implementasi & Evaluasi \\
\hline $\begin{array}{l}\text { Kamis, } 18 \\
\text { Maret } 2021 \\
\text { 10:30 WIB }\end{array}$ & $\begin{array}{l}\text { 1. Data: } \\
\text { Tanda dan gejala : Hilang } \\
\text { kepercayaan diri, merasa gagal } \\
\text { karena tidak mampu mencapai } \\
\text { keinginan sesuai ideal diri, } \\
\text { perasaan tidak berharga, tidak } \\
\text { berarti dan rendah diri yang } \\
\text { berkepanjangan } \\
\text { 2. Diagnosa Keperawatan } \\
\text { Harga Diri Rendah } \\
\text { Tindakan keperawatan: } \\
\text { Sp 1 Harga Diri Rendah : } \\
\text { Mengidentifikasi kemampuan dan } \\
\text { aspek positif yang dimiliki pasien }\end{array}$ & 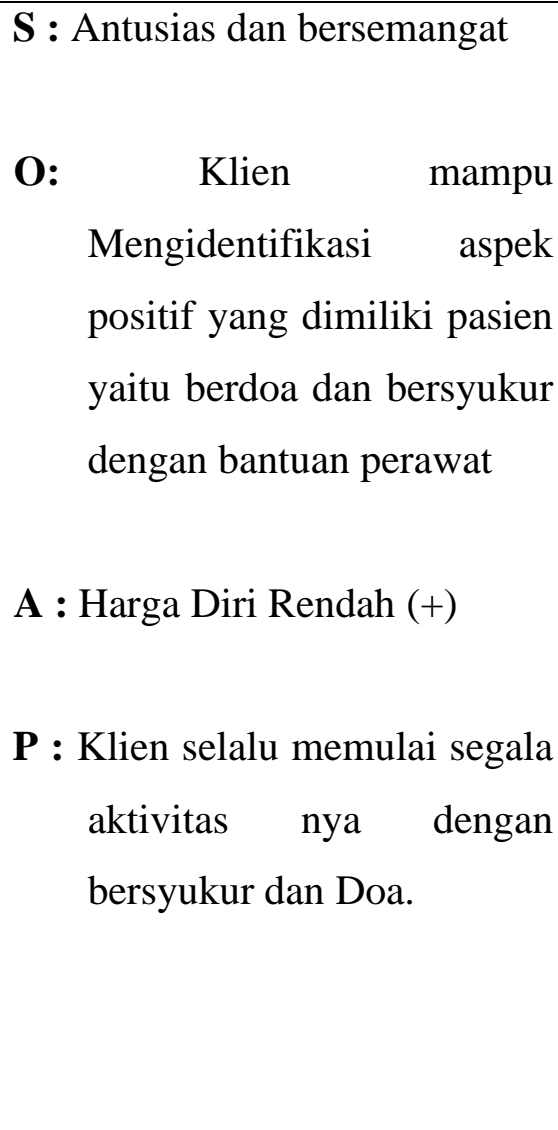 \\
\hline
\end{tabular}




\begin{tabular}{|c|c|c|}
\hline & $\begin{array}{l}\text { 4. RTL: } \\
\text { Sp2 Harga Diri Rendah: } \\
\text { a. Menilai kemampuan yang } \\
\text { dapat digunakan } \\
\text { b. Menetapkan atau memilih } \\
\text { kegiatan sesuai kemampuan } \\
\text { c. Melatih kegiatan sesuai } \\
\text { kemampuan yang dipilih } 1\end{array}$ & \\
\hline $\begin{array}{l}\text { Kamis, } 18 \\
\text { Maret } 2021 \\
\text { 10:00 WIB }\end{array}$ & $\begin{array}{l}\text { 1. Data: } \\
\text { Tanda dan gejala : Hilang } \\
\text { kepercayaan diri, merasa gagal } \\
\text { karena tidak mampu mencapai } \\
\text { keinginan sesuai ideal diri, } \\
\text { perasaan tidak berharga, tidak } \\
\text { berarti dan rendah diri yang } \\
\text { berkepanjangan } \\
\text { 2. Diagnosa Keperawatan } \\
\text { Harga Diri Rendah } \\
\text { Tindakan keperawatan: } \\
\text { Sp 2 Harga Diri Rendah : } \\
\text { a. Menilai kemampuan yang } \\
\text { dapat digunakan } \\
\text { b. Menetapkan atau memilih } \\
\text { kegiatan sesuai kemampuan } \\
\text { c. Melatih kegiatan sesuai } \\
\text { kemampuan yang dipilih } 1 \\
\text { RTL: } \\
\text { Sp } 3 \text { : Melatih kegi } \\
\text { atan sesuai kemampuan yang } \\
\text { 4ipilih } 2\end{array}$ & $\begin{aligned} \mathbf{S}: & \text { Senang dan antusias } \\
\mathbf{O}: & \text { Klien mampu memilih dan } \\
& \text { melatih kegiatan sesuai } \\
& \text { kemampuan yaitu masak } \\
& \text { dengan bantuan } \\
\text { A : } & \text { Harga Diri Rendah }(+) \\
\mathbf{P}: & \text { Klien melatih kemampuan } \\
& \text { memasak yang dimiliki nya }\end{aligned}$ \\
\hline
\end{tabular}




\begin{tabular}{|c|c|c|}
\hline $\begin{array}{l}\text { Sabtu, } 20 \\
\text { Maret } 2021 \\
\text { 10:30 WIB }\end{array}$ & $\begin{array}{l}\text { 1. Data: } \\
\text { Tanda dan gejala : Hilang } \\
\text { kepercayaan diri, merasa gagal } \\
\text { karena tidak mampu mencapai } \\
\text { keinginan sesuai ideal diri, } \\
\text { perasaan tidak berharga, tidak } \\
\text { berarti dan rendah diri yang } \\
\text { berkepanjangan } \\
\text { 2. Diagnosa Keperawatan } \\
\text { Harga Diri Rendah } \\
\text { Tindakan keperawatan: } \\
\text { Sp 3 Harga Diri Rendah : } \\
\text { Melatih kegiatan } \\
\text { kemampuan yang dipilih } 2 \\
\text { RTL: } \\
\text { Sp } 4 \text { Mesuai } \\
\text { kemampuan yang dipilih } 3\end{array}$ & $\begin{array}{l}\text { A : Harga Diri Rendah }(+) \\
\text { P : } \\
\text { - } \text { Berdoa, Mengikuti } \\
\\
\quad \text { ibadah } \\
\text { - } \text { Membantu Masak } \\
\text { - } \text { Menyuci piring }\end{array}$ \\
\hline $\begin{array}{l}\text { Selasa,22 } \\
\text { Maret } 2021 \\
11.00 \text { WIB }\end{array}$ & $\begin{array}{l}\text { 1. Data: } \\
\text { Tanda dan gejala : Hilang } \\
\text { kepercayaan diri, merasa gagal } \\
\text { karena tidak mampu mencapai } \\
\text { keinginan sesuai ideal diri, } \\
\text { perasaan tidak berharga, tidak } \\
\text { berarti dan rendah diri yang } \\
\text { berkepanjangan } \\
\text { 2. Diagnosa Keperawatan } \\
\text { Harga Diri Rendah } \\
\text { 3. Tindakan keperawatan: } \\
\text { Sp 4 Harga Diri Rendah : }\end{array}$ & $\begin{array}{l}\text { S : Senang } \\
\text { O : Klien mampu melatih } \\
\text { kegiatan sesuai kemampuan } \\
\text { yang dipilih yaitu menyapu } \\
\text { rumah dengan mandiri } \\
\text { A : Harga diri rendah (+) } \\
\text { P : } \\
\text { - Berdoa, } \\
\text { ibadah }\end{array}$ \\
\hline
\end{tabular}




\begin{tabular}{|l|l|l|}
\hline & $\begin{array}{l}\text { Melatih kegiatan sesuai } \\
\text { kemampuan yang dipilih 3 }\end{array}$ & $\bullet$ Menyuci piring \\
& $\begin{array}{l}\text { RTL : } \\
\text { Harga Diri Rendah : Follow up Halaman } \\
\text { dan evaluasi SP 1-4 }\end{array}$ \\
\hline
\end{tabular}

\begin{tabular}{|c|c|c|}
\hline Hari/tgl & Implementasi & Evaluasi \\
\hline $\begin{array}{l}\text { selasa, } 23 \\
\text { Maret } 2021 \\
\text { 10:30 WIB }\end{array}$ & $\begin{array}{l}\text { 1. Data: } \\
\text { Tanda dan gejala : mudah marah- } \\
\text { marah, mudah tersinggung,tatapan } \\
\text { sinis, ,suka menyendiri, merasa } \\
\text { tidak dihargai } \\
\text { 2. Diagnosa Keperawatan } \\
\text { Risiko Perilaku Kekerasan } \\
\text { Harga Diri Rendah } \\
\text { 3. Tindakan keperawatan: } \\
\text { Sp 1 Risiko Perilaku Kekerasan: } \\
\text { Mengidentifikasi penyebab risiko } \\
\text { perilaku kekerasan yaitu jika } \\
\text { kemauan klien tidak dituruti } \\
\text { Mengidentifikasi tanda dan gejala } \\
\text { risiko perilaku kekerasan yaitu } \\
\text { klien marah, mengamuk tanpa } \\
\text { jelas, merusak barang-barang, dan } \\
\text { cenderung melukai orang lain } \\
\text { Menyebutkan cara mengontrol } \\
\text { risiko perilaku kekerasan adalah } \\
\text { dengan latihan fisik } 1: \text { tarik napas } \\
\text { dalam latihan fisik } 2 \text { : pukul kasur } \\
\text { bantal } \\
\text { Membantu klien latihan tarik } \\
\text { napas dalam dan pukul kasur }\end{array}$ & 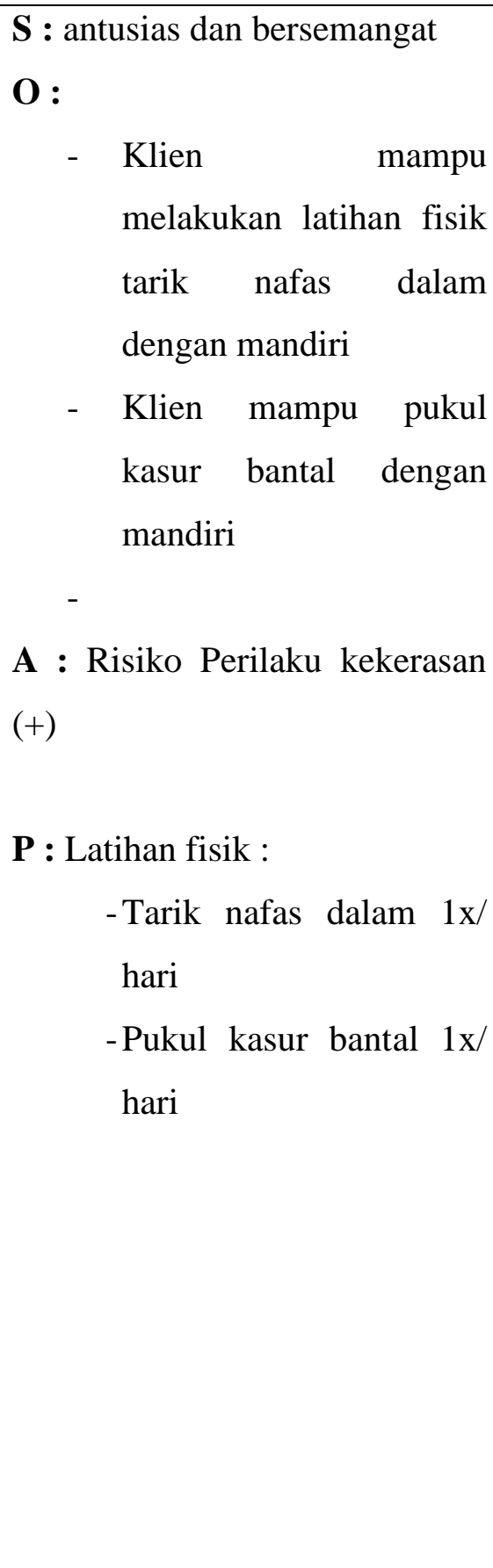 \\
\hline
\end{tabular}




\begin{tabular}{|l|l|l|}
\hline 4. & RTL: \\
Sp2 Risiko Perilaku Kekerasan: & \\
- Mengontrolrisiko perilaku \\
kekerasan dengan minum obat \\
secara teratur
\end{tabular}

\begin{tabular}{|c|c|c|}
\hline Hari/tgl & Implementasi & Evaluasi \\
\hline $\begin{array}{l}\text { Rabu, } 24 \\
\text { Maret } 2021 \\
\text { 10:30 WIB }\end{array}$ & $\begin{array}{l}\text { 1. Data: } \\
\text { Tanda dan gejala : pasien tanpat } \\
\text { katakutan dan merasa cemas } \\
\text { dengan suara yang didengarnya. } \\
\text { Kemampuan : meminum air putih } \\
\text { katika merasa cemas katika suara } \\
\text { bisikan itu datang } \\
\text { 2. Diagnosa Keperawatan } \\
\text { gangguan persepsi sensori : } \\
\text { Halusinasi pendengaran } \\
\text { 3. Tindakan keperawatan: } \\
\text { Sp 1: } \\
\text { - Mengidentifikasi isi, frekuensi } \\
\text { waktu terjadi, situasi, pencatus, } \\
\text { perasaan dan respon halusinasi } \\
\text { Suara yang dating dibisikan pasien } \\
\text { membuat klien takut dan cemas, } \\
\text { dan suara itu dating siang hari } \\
\text { katika klien sedang sendiri dan } \\
\text { beristirahata dank lien selalu } \\
\text { minum air putih untuk mengatasi } \\
\text { cemasnya } \\
\text { Menyebutkan cara mengontrol } \\
\text { halusinasi dengan Menghardik. }\end{array}$ & 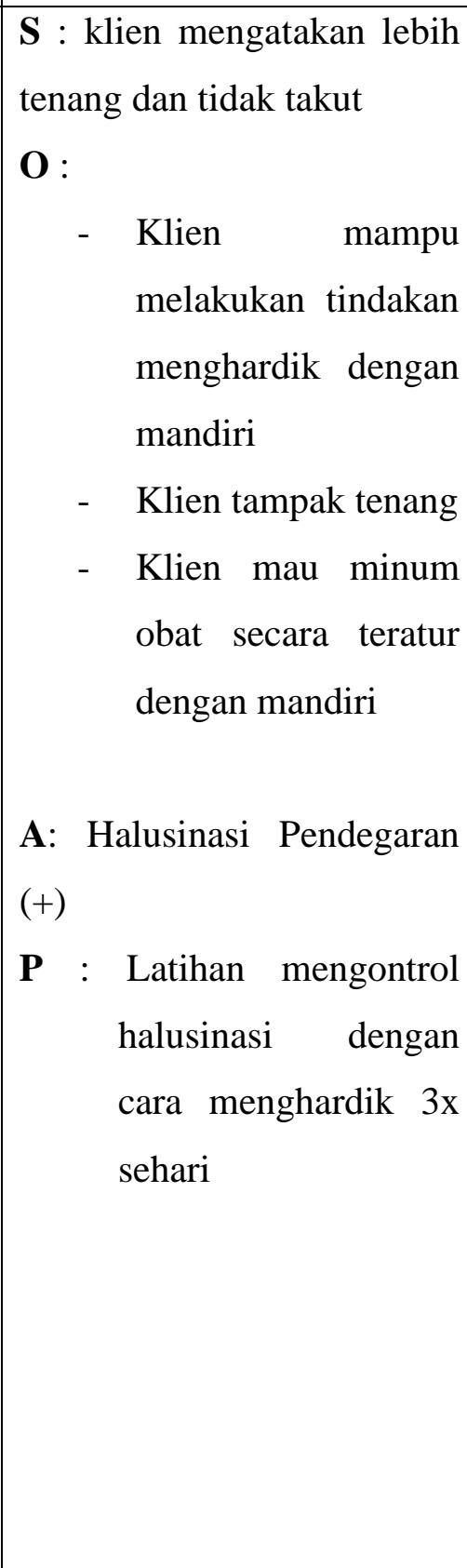 \\
\hline
\end{tabular}




\begin{tabular}{|c|c|c|}
\hline & $\begin{array}{l}\text { Sp2: } \\
\text { Mengontrol halusinasi dengan } \\
\text { minum obat secara teratur } \\
\text { 4. RTL: } \\
\text { Sp3 : } \\
\text { - Mengontrol halusinasi dengan } \\
\quad \text { bercakap-cakap dengan ornag } \\
\text { lain } \\
\text { Sp } 4 \text { : } \\
\text { - Mengontrol halusinasi dengan } \\
\text { melakukan kegiatan terjadwal }\end{array}$ & \\
\hline $\begin{array}{l}\text { kamis, } 25 \\
\text { Maret } 2021 \\
\text { 10:00 WIB }\end{array}$ & $\begin{array}{l}\text { 1. Data: } \\
\text { Tanda dan gejala : pasien tanpat } \\
\text { katakutan dan merasa cemas } \\
\text { dengan suara yang didengarnya. } \\
\text { Kemampuan : meminum air putih } \\
\text { katika merasa cemas katika suara } \\
\text { bisikan itu datang } \\
\text { 2. Diagnosa Keperawatan } \\
\text { gangguan persepsi sensori : } \\
\text { Halusnasi pendengaran } \\
\text { Tindakan keperawatan: } \\
\text { Sp } 3 \text { :Mengontrol halusinasi dengan } \\
\text { becakap-cakap dengan orang lain. } \\
\text { menyarankan klien untuk bercakap } \\
\text { cakap dengan keuarga, dan } \\
\text { memberitahukan kepada keluarga } \\
\text { harus mampu memndampingi dna } \\
\text { menemani pasien dalam berbicara } \\
\text { Sp } 4 \text { mengontrol halusinasi } \\
\text { dengan melakukan kegiatan } \\
\text { terjadwal }\end{array}$ & 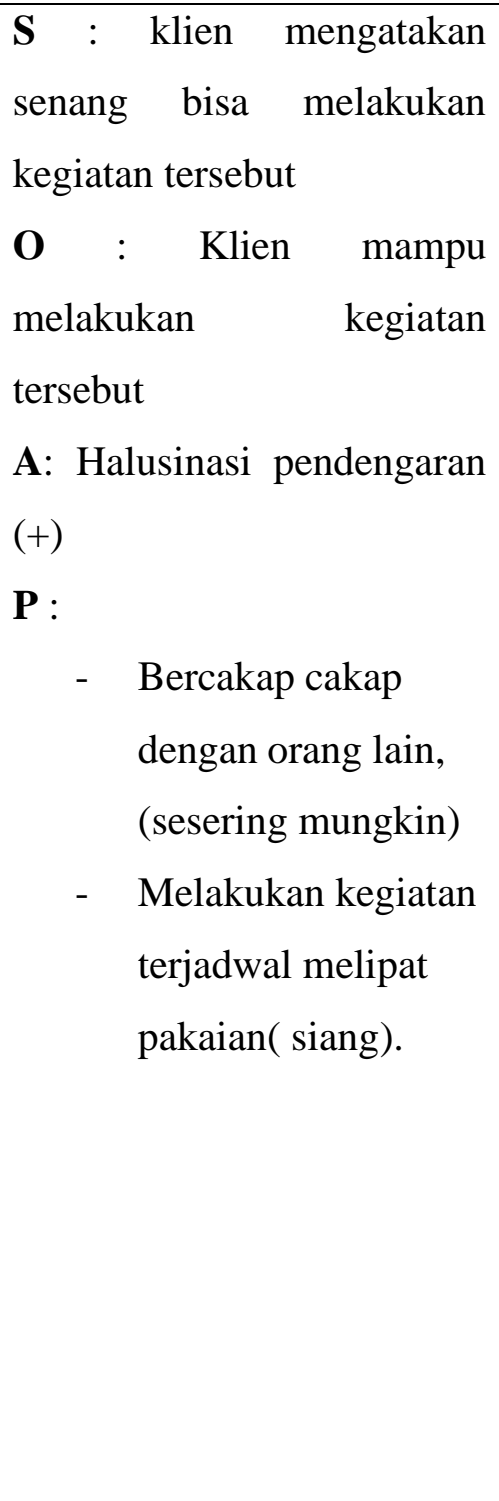 \\
\hline
\end{tabular}




\begin{tabular}{|c|c|c|}
\hline & $\begin{array}{l}\text { klien dirumah memiliki kegiatan } \\
\text { terjadwal yaitu mmebersihkan } \\
\text { rumah dan menyuci piring satiap } \\
\text { harinya. } \\
\text { 4.RTL: } \\
\text { - Evaluasi kemampuan pasien } \\
\text { dalam memahami tindakan Sp1 } \\
\text { sd Sp } 4\end{array}$ & \\
\hline $\begin{array}{l}\text { kamis, } 25 \\
\text { Maret } 2021 \\
\text { 10:30 WIB }\end{array}$ & $\begin{array}{l}\text { 1. mengevaluasi kemampuan klien } \\
\text { dalam mengontrol halusinasi } \\
\text { dengan cara menghardik } \\
\text { 2. mengevaluasi klien menontrol } \\
\text { halusinasi bercakap-cakap } \\
\text { dengan orang lain } \\
\text { 3. mengontrol halusinasi dengan } \\
\text { melakukan kegiatan terjadwal }\end{array}$ & $\begin{array}{l}\mathbf{S}: \text { klien mengatakan } \\
\text { merasan baik, dan tidak } \\
\text { cemas satelah melakukan } \\
\text { kegiatan beberapa hari ini } \\
\mathbf{O}: \text { Klien mampu } \\
\text { melakukan kegiatan } \\
\text { menghardik dengan mandiri } \\
\mathbf{A}: \text { Halisinasi pendengaran } \\
\mathbf{P}: \text { Klien melakukan } \\
\text { kegiatan satiap hari dan } \\
\text { siang hari }\end{array}$ \\
\hline
\end{tabular}




\section{BAB 4 \\ PEMBAHASAN}

Setelah penulis melaksanakan asuhan keperawatan kepada Tn.S dengan Isolasi Sosial di Yayasan pemenangan Jiwa, maka penulis pada BAB ini akan membahasan kesenjangan antara teoritis dengan tinjauan kasus. Pembahasan dimulai melalui tahapan proses keperawatan yaitu pengkajian, diagnosa keperawatan, perencanaan, pelaksanaan dan evaluasi.

\subsection{Tahap Pengkajian}

Selama pengkajian dilakukan pengumpulan data dari beberapa sumber yaitu dari pasien dan pengawas yayasan. Mahasiswa mendapat sedikit kesulitan dalam menyimpulkan data kerena keluarga pasien jarang mengkunjungi pasien di yayasan pemenang jiwa. Maka mahasiwa melakukan pendekatan pada pasien melalui komunikasi terapautik yang lebih terbuka membantu pasien untuk memecahkan perasaannya dan juga melakukan observasi kepada pasien. Adapau upaya tersebut yaitu :

1. Melakukan pendekatan dan membina hubungan saling percaya diri pada pasien agar pasien lebih terbuka dan lebih percaya dengan menggunakan perasaan.

2. Mengadakan pengkajian pasien dengan wawancara dan tidak menemukan kesenjangan karena di temukan hal sama seperti diteori bahwasanya Isolasi sosial meruakan keadaan dimana sseorang individu mengalami penurunan atau bahkan sama sekali tidak mampu berinteraksi dengan orang lain disekitarnya. Pasien isolasi soasial mengalami gangguan dalam berinteraksi dan mengalami perilaku tidak ingin berkomunikasi dengan orang lain disekitarnya, lebih menyukai berdiam diri, mengurung diri, dan menghindar dari orang lain (Pardede, 2020).

\subsection{Tahap Perencanaan}

Perencanaan dalam proses keperawatan lebih dikenal dengan rencana asuhan keperawatan yang merupakan tahap selanjutnya setelah pangkajian dan penentuan diagnosa keperawatan. Pada tahap perencanaan penulis 
hanya menyusun rencana tindakan keperawatan sesuai dengan pohon masalah keperawatan yaitu : isolasi sosial. Pada tahap ini antara tinjauan teoritis dan tinjaun kasus tidak ada kesenjangan sehingga penulis dapat melaksanakan tindakan seoptimal mungkin dan didukung dengan seringnya bimbingan dengan pembimbing. Secara teoritis digunakan cara strategi pertemuan sesuai dengan diagnosa keperawatan yang muncul saat pengkajian. Adapun upaya yang dilakukan penulis yaitu :

1. Isolasi Sosial

a. Mengidentifikasi isi Isolasi Sosial

b. Mengidentifikasi waktu terjadi Isolasi Sosial

c. Mengidentifikasi situasi pencetus Isolasi Sosial

d. Mengidentifikasi respon terhadap Isolasi Sosial

e. Membantu pasien mempraktekan latihan cara berkenalan dengan dua orang atau lebih

f. Menjelaskan keutungan dan kerugian mempunya teman

g. Melatih pasien bercakap - cakap sambil melakukan kegiatan harian

h. Melatih pasien berbicara soial : seperti meminta sesuatu, berbelanja dan sebagainya

i. Mengevaluasi jadwal kegiatan harian pasien

\subsection{Tahap Implementasi}

Pada tahap implementasi, penulis hanya mengatasi 1 masalah keperawatan yakni: diagnosa keperawatan Isolasi Sosial di karenakan masalah utama yang dialami klien. Pada diagnosa keperawatan Isolasi dilakukan strategi pertemuan yaitu mengidentifikasi isolasi sosial, menjelaskan keuntungan dan kerugian mempunyai teman,. Strategi pertemuan yang kedua yaitu membantu pasien mempratekkan cara berkenalan dengan dua orang atau lebih, strategi pertemuan ketiga yaitu melatih pasien bercakap cakap sambil melakukan kegiatan harian, pertemuan ke empat yaitu melatih pasien berbicara sosial seperti meminta bantuan, belanja, dan sebgainya. 


\subsection{Tahap Evlaluasi}

Pada tinjauan teoritis evaluasi yang diharapkan adalah :

1. Pasien mempercayai perawat sebagai terapis

2. Dapat mengidentifikasi dan mengontrol Isolasi Sosial

3. Dapat mengendalikan Isolasi Sosial melalui berkenalan dengan dua orang atau lebih

4. Dapat mengendalikan Isolasi Sosial dengan cara bercakap cakap sambil melakukan kegiatan harian.

5. Dapat mengendalikan Isolasi Sosial dengan cara berbicara sosial seperti : meminta bantuan, berbelanja, dan lain sebagainya..

Pada tinjauan kasus evaluasi yang dihasilkan adalah :

1. Klien sudah dapat mengontrol dan mengidentifikasi Isolasi Sosial

2. Klien dapat mengendalikan Isolasi Sosial melalui berkenalan dengan dua orang atau lebih.

3. Klien dapat mengendalikan Isolasi Sosial dengan cara bercakap cakap sambil melakukan kegiatan harian.

Klien dapat mengendalikan Isolasi Sosial dengan cara berbicara sosial seperti: meminta bantuan, berbelanja, dan lain sebagainya 


\section{BAB 5 \\ PENUTUP}

\subsection{Kesimpulan}

Setelah menguraikan tentang proses keperawatan pada Tn.S dan disimpulkan bahwa pasien dapat mengontrol Isolasi Sosial dengan terapi yang di ajarkan oleh mahasiwa. Dimana pasien suda dapat mengetahui keuntungan dan kerugian mempunyai teman,dapat melakukan cara berkenalan dengan dua orang atau lebih, bercakap cakap sambil melakukan kegiatan harian, berbicara sosial seperti : meminta sesuatu, belanja dan sebagainya dan dilakukan dalam kegiatan harian pasien di Yayasan.

\subsection{Saran}

1. Bagi pasien hendaknya dapat berinteraksi sosial dengan menerapkan strategi pelaksanaan,menyadari keuntungan memiliki teman dan kerugian tidak memiliki teman, melakukan komunikasi kepada sesama atau dilingkungan sekitar, meminum obat secara teratur dan dapat berinteraksi sosial seperti meminta sesuatu kepada teman atau dilingkungan sekitar.

2. Bagi yayasan pemenang jiwa sumatera hendaknya memberikan pelayanan kesehatan yang baik dan membuat suasana lingkungan menjadi lebih nyaman agar pasien mampu bersosialisasi dengan orang lain yang berada disekitar lingkungannya. 


\section{DAFTAR PUSTAKA}

Astuti, L. (2020). Studi Dokumentasi Isolasi Sosial Pada Pasien Dengan Skizofrenia. Akademi Keperawatan YKY Yogyakarta. http://repository.akperykyjogja.ac.id/id/eprint/295

Ayu Candra Kirana, S. (2018). Gambaran Kemampuan Interaksi Sosial Pasien Isolasi Sosial Setelah Pemberian Social Skills Therapy Di Rumah Sakit Jiwa. Journal of Health Sciences, 11(1). https://doi.org/10.33086/jhs.v11i1.122

Banjar, B. R. S. U. K., \& Maulana, K.(2016). Asuhan keperawatan pada ny. R dengan isolasi sosial: menarik diri akibat skizofrenia di ruang tanjung. http://cdn.stikesmucis.ac.id/13DP277033.pdf

Damanik, R. K., Pardede, J. A., \& Manalu, L. W. (2020). Terapi Kognitif Terhadap Kemampuan Interaksi Pasien Skizofrenia Dengan Isolasi Sosial. Jurnal Ilmu Keperawatan dan Kebidanan, 11(2), 226-235. http://dx.doi.org/10.26751/jikk.v11i2.822

Enggar Ayuningtyas, P. A. L. U. P. I. (2020). Studi Literatur: Asuhan Keperawatan Pada Pasien Skizofrenia Dengan Masalah Keperawatan Isolasi Sosial Menarik Diri (Doctoral dissertation, Universitas Muhammadiyah Ponorogo).

Fitria. (2019). Buku Ajar Keperawatan Jiwa (Advance Mental Health Nursing). Bandung : Refika Aditama. https://onesearch.id/Record/IOS3318.

Gaol, H. L. (2021). Asuhan Keperawatan Jiwa Pada Ny. I Dengan Masalah Halusinasi Pendengaran. doi. 10.31219/osf.io/r5anf

Habeahan, H. (2020). Perencanaan Keperawatan Dalam Proses Menentukan Diagnosa Keperawatan Dengan Melakukan Cara Berpikir Kritis. https://osf.io/5y $3 \mathrm{gm} /$ download?format=pdf

Hasriana, H., Nur, M., \& Anggraini, S. (2013). Pengaruh terapi aktivitas kelompok sosialisasi terhadap kemampuan bersosialisasi pada klien isolasi sosial menarik diri di Rumah Sakit Khusus Daerah Provinsi Sulawesi Selatan. Jurnal Ilmiah Kesehatan Diagnosis, 2(6), 74-79. http://ejournal.stikesnh.ac.id/index.php/jikd/article/view/485

Hermawan, B. (2015). Asuhan Keperawatan Jiwa Pada Tn. S Dengan Gangguan Isolasi Sosial: Menarik Diri Di Ruang Arjuna RSJ Daerah Surakarta (Doctoral dissertation, Universitas Muhammadiyah Surakarta). http://eprints.ums.ac.id/id/eprint/34432

Kurniasari, C. I., Dwidiyanti, M., \& Padmasari, S. (2019). Terapi Keperawatan Dalam Mengatasi Masalah Interaksi Sosial pada Pasien Skizofrenia: Literatur Review. Jurnal Ilmu Keperawatan Jiwa, 2(1), 41-46. http://dx.doi.org/10.32584/jikj.v2i1.276 
Latifah, L., \& Rahayu, P. (2020). Pengaruh terapi social skill training tahap melatih kemampuan berkomunikasi pada pasien skizofrenia. Jurnal'Aisyiyah Medika, 5(1). https://doi.org/10.36729/jam.v5i1.308

Muhith, A. (2015). Pendidikan Keperawatan Jiwa : Teori dan Aplikasi. Penerbit Andi.

Pardede, J. A. (2018). Pelaksanaan Tugas Keluarga Dengan Frekuensi Kekambuhan Pasien Skizofrenia Dengan Masalah Isolasi Sosial. Jurnal Keperawatan Jiwa, 6(2).

Pardede, J. A., Hamid, A. Y. S., \& Putri, Y. S. E. (2020). Application of Social Skill Training using Hildegard Peplau Theory Approach to Reducing Symptoms and the Capability of Social Isolation Patients. Jurnal Keperawatan, 12(3), 327-340 https://doi.org/10.32583/keperawatan.v12i3.782

Puspitawati, P. H. (2020). Gambaran Asuhan Keperawatan Pemberian Terapi Aktivitas Kelompok Sosialisasi Sesi Iv Bercakap-Cakap Topik Tertentu Untuk Mengatasi Isolasi Sosial Pada Pasien Skizofrenia Di UPTD RSJ Dinkes Provinsi Bali Tahun 2020 (Doctoral dissertation, Poltekkes Denpasar Jurusan Keperawatan). http://repository.poltekkes-denpasar.ac.id/id/eprint/5030

Rahmadani, K. D. (2019). Asuhan Keperawatan Jiwa Pada Klien Dengan Perilaku Kekerasan Di Ruang Tiung Rumah Sakit Jiwa Daerah Atma Husada Mahakam Samarinda. http://repository. poltekkes-kaltim.ac.id/id/eprint/402

Rahayuningsih, A., \& Muharyari, W. (2016). Pengaruh Pemberian Terapi Aktivitas Kelompok Sosialisasi Terhadap Perubahan Perilaku Klien Isolasi $\begin{array}{lllll}\text { Sosial. NERS Jurnal Keperawatan, } & 8(2), & 105 .\end{array}$ https://doi.org/10.25077/njk.8.2.105-114.2012

Sinaga, Y. C. (2020). Hubungan Pemberian Tak Sosialisasi Terhadap Kemampuan Interaksi Sosial Pada Pasien Isolasi Sosial Di Rsj Prof. Dr. M. Ildrem Medan 2019.http://poltekkes.aplikasi-akademik.com/xmlui/handle/123456789/2181

Siskayanti, A., Nugroho, A., \& Hartoyo, M. (2012). Pengaruh terapi komunikasi terapeutik terhadap kemampuan berinteraksi klien isolasi sosial di rsjd dr. Amino gondohutomo semarang. Karya Ilmiah.

Sukaesti, D. (2019). Sosial Skill Training Pada Klien Isolasi Sosial. Jurnal Keperawatan Jiwa, 6(1), 19-24.https://doi.org/10.26714/jkj.6.1.2018.19-24

Sumarno, K. (2019). Asuhan Keperawatan Pada Tn. FPB Dengan Isolasi Sosial: Menarik Diri Di Ruang Rawat Inap Rumah Sakit Jiwa Naimata Kupang Provinsi Nusa Tenggara Timur. Skripsi, Poltekkes Kemenkes Kupang.

Sutejo. (2017). Konsep dan Praktik Asuhan Keperawatan Kesehatan Jiwa: Ganguan Jiwa dan Psikososial. Yogyakarta: PT. Pustaka Baru. 
